\title{
Effect of arsenic on paracetamol binding to bovine serum albumin using site specific probes
}

\author{
${ }^{*}$ Riaz Uddin', Nadia Saffoon ${ }^{2}$, Md. Ashraful Alam ${ }^{3}$ \\ ${ }^{1}$ Department of Pharmacy, Stamford University Bangladesh, Dhaka, 1217, Bangladesh \\ ${ }^{2}$ Marketing Strategy Department, Ziska Pharmaceuticals Ltd., Dhaka, 1000, Bangladesh \\ ${ }^{3}$ School of Biomedical Sciences, The University of Queensland, Brisbane, 4072, Australia
}

\begin{abstract}
Arsenic contamination in groundwater is a global health challenge. A large number of people worldwide are affected by arsenic poisoning. Paracetamol is a widely used analgesic-antipyretic drug. Effect of arsenic on paracetamol binding to protein has been investigated using two site specific probes and equilibrium dialysis method was used for the experiment. In absence of any site specific probes free concentration of paracetamol bound to bovine serum albumin increased from $3.95 \pm 1.164 \%$ to $25.36 \pm 1.164 \%$. In presence of site-I specific probe warfarin sodium the $\%$ release of drug was steady at around $14 \%$. But in presence of site-II specific probe an increment of free drug concentration was observed from $14.38 \pm 1.164 \%$ to $54.72 \pm 1.552 \%$. Thus it can be assumed that the free concentration of paracetamol was increased to a greater extent in presence of arsenic and probably arsenic bound to site-II of BSA. Thus arsenic may displace paracetamol by binding with high affinity binding site, site-II in the BSA and probably arsenic has little effect to site-I.
\end{abstract}

Key Words: Warfarin sodium, diazepam, equilibrium dialysis, drug-drug interaction, protein binding.

\section{INTRODUCTION}

Arsenic contamination of groundwater has led to a massive epidemic of arsenic poisoning in Bangladesh and neighboring countries. It is estimated that approximately 57 million people are drinking groundwater with arsenic concentration elevated above the World Health Organization's standard of 10 parts per billion (Uddin and Huda, 2011). Arsenic contamination of ground water in context to Bangladesh is well documented (Uddin and Huda, 2011; Uddin et al., 2011; Uddin et al., 2012). Chronic arsenic exposure is associated with many human health conditions, including skin lesions and cancers of the liver, lung, bladder and skin (Uddin et al., 2011). It is also associated with many non-cancer health effects, such as adverse reproductive outcomes, neurological disorders, and impaired

\footnotetext{
*Corresponding Author:

Riaz Uddin, Senior Lecturer

Dept. of Pharmacy, Stamford University Bangladesh

51 Siddeswari Road

Dhaka, 1217, Bangladesh

E-mail:kp_ruddin@yahoo.com

Contact No.: +8801680106009
}

cognitive development in children (Wasserman et al., 2004). Paracetamol is a common analgesicantipyretic drug which has been included in the $15^{\text {th }}$ model list of essential medicines by WHO as nonopioids and nonsteroidal anti-inflammatory medicines (NSAIMs) (WHO 2007). The drug is thought to be one of the safest drugs. But toxicity associated with this drug is also common. Paracetamol toxicity results when it is taken at very large doses (Dong et al., 2000). Paracetamol overdose results in more calls to poison control centers in the USA than overdose of any other pharmacological substance, accounting more than 100,000 calls, as well as 56,000 emergency room visits, 2,600 hospitalizations and 458 deaths due to acute liver failure per year (Lee, 2004). A recent study of cases of acute liver failure between November 2000 and October 2004 by the Center for Disease Control and Prevention (US) found that paracetamol was the cause of $41 \%$ of all cases in adults and $25 \%$ of cases in children (Bower et al., 2007). As paracetamol is widely available, there is a large potential for overdose and toxicity (Sheen et al., 2002). 
The reduction in the extent of binding of a drug to protein occurred by the presence of other drug is termed as drug-drug interaction or drug displacement which may increase the free concentration of the displaced drug and may lead to higher pharmacological as well as toxic effects (Rahman et al., 1993). Keeping these considerations in mind paracetamol, a commonly used non-steroidal antiinflammatory drug has been investigated to determine the effect of arsenic on the binding of the drugs at the binding sites of bovine serum albumin.

\section{MATERIALS AND METHODS}

Drug and reagents used in the experiment: Paracetamol (General Pharmaceutical Ltd., Bangladesh). warfarin sodium and diazepam (Incepta Pharmaceuticals Ltd., Bangladesh), disodium hydrogen phosphate $\left(\mathrm{Na}_{2} \mathrm{HPO}_{4}\right)$, potassium dihydrogen phosphate $\left(\mathrm{KH}_{2} \mathrm{PO}_{4}\right)$, cellulose nitrate membrane (Medicell International Ltd. Liverpool Road, London; mol. Wt. 1200 Daltons), Bovine Serum Albumin (BSA) (fatty acid free, fraction $\mathrm{V}$, molecular wt 66,500 from Sigma Chemical Ltd.), arsenic trioxide ( $\left.\mathrm{As}_{2} \mathrm{O}_{3}\right)$.

Instrument used: $\mathrm{pH}$ Meter (HANNA Microprocessor pH Meter, Portugal), HACH-4000 UV/VIS Spectrophotometer (USA), Metabolic Shaking Incubator (Clifton Shaking Bath, Nical electro Ltd., England) Micro Syringe (well. Liang. Jin. Yang.q.I., China.).

Method used: Equilibrium dialysis was employed in the study (Singlas, 1987).

Site-specific probes method: Different site-specific probes have been used to enhance the understanding of the drug-BSA interaction and thereby characterization of binding sites of the drugs used in the study on the BSA molecule (Sudlow et al., 1975; Sudlow et al., 1976; Singlas, 1987). Two site-specific probes were used; warfarin sodium (site I-specific probe) and diazepam (site II-specific probe) for the identification of the binding sites of the drugs on BSA. In the direct procedure, the ratio of BSA and probe (either warfarin or diazepam) was 1:1 $\left(2 \times 10^{-5} \mathrm{M}: 2 \times 10^{-5} \mathrm{M}\right)$, and different concentrations of drug were added. In the reverse procedure, the ratio of BSA and drug was 1:1 $\left(2 \times 10^{-5} \mathrm{M}: 2 \times 10^{-5} \mathrm{M}\right)$, and different concentrations of probe (Site I-specific warfarin sodium or Site IIspecific diazepam) were added. After conducting equilibrium dialysis, the free concentrations of probe were determined in direct procedure and reverse procedure respectively.

Standard curve preparation: Standard curve was prepared by using the various concentrations and their corresponding absorbance at $\mathrm{pH}$ 7.4. UV spectrophotometric scanning of the drug paracetamol showed maximum absorbance of the UV light at $246 \mathrm{~nm}$. Paracetamol has found linearity at a concentration of $10-80 \mu \mathrm{M} / \mathrm{ml}$ with a confidence level of 0.9995 at $\mathrm{pH} 7.4$ with linear equation $\mathrm{Y}=$ $0.0911 X+0.0003$ which was used to calculate the concentration of the drug being investigated.

Effect of arsenic on paracetamol bound to BSA in absence of site specific probes

$3.0 \mathrm{ml}$ of previously prepared $2 \times 10^{-5} \mathrm{M}$ BSA solution was taken in each of seven previously cleaned and dried test tubes. $6 \mu \mathrm{L}$ of $1 \times 10^{-2} \mathrm{M}$ paracetamol solution was taken in each of six cleaned and dried test tubes. The final ratio between protein and drug was 1:1 $\left(2 \times 10^{-5} \mathrm{M}: 2 \times 10^{-5} \mathrm{M}\right)$ in each of six test tubes. The seventh test tube containing only BSA was marked as blank. Arsenic was added with an increasing concentration in five out of six test tubes containing 1:1 mixture of protein and drug to make the final ratio of protein, paracetamol and arsenic 1:1:0, 1:1:1, 1:1:2, 1:1:4, 1:1:6 and 1:1:8. Arsenic was not added to one test tube. The solution mixture was then properly mixed and allowed to stand for 15 minutes for the confirmation of maximum binding to BSA. After 15 minutes the solutions were pipetted out and poured into seven different semipermeable membrane tubes. Both the end of the membrane was clipped and was ensured that there was no leakage. The tubes containing drug mixture were immerged in seven $50 \mathrm{ml}$ conical flasks containing $30 \mathrm{ml}$ of phosphate buffer solution at $\mathrm{pH}$ 7.4. The conical flasks were then placed in a mechanical shaker and were shacked at $27^{\circ} \mathrm{C}$ temperature with $20 \mathrm{rpm}$ continuously for six hours uninterruptedly to complete the dialysis. After shaking is complete samples were collected from each flask. Free concentrations of paracetamol were measured by using a UV-VIS spectrophotometer at a wavelength of $246 \mathrm{~nm}$. 


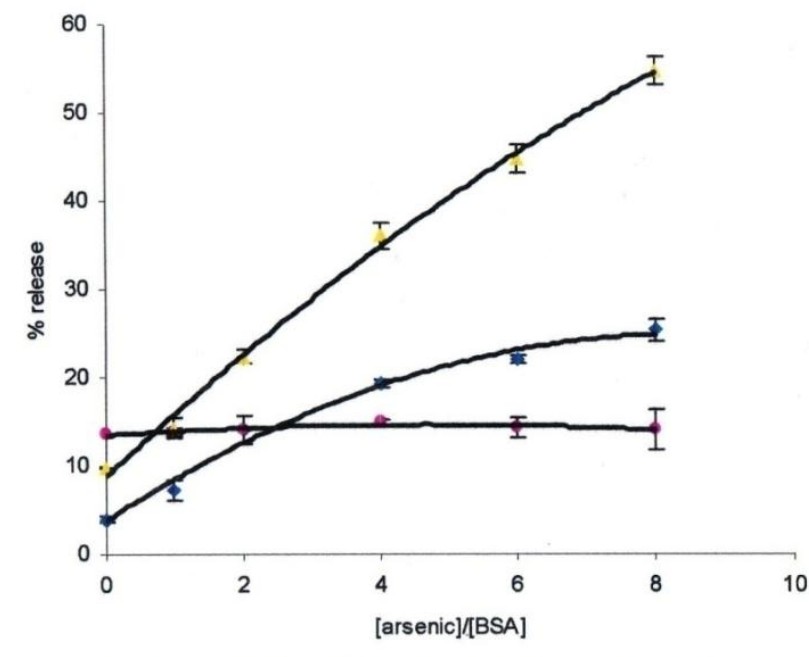

Free concentration of Paracetamol in absence of probe $(\bullet)$ in presence of site-I specific probe $(\bullet)$ in presence of site-II specific probe $(\Delta)$

Figure 1: Effect of arsenic on paracetamol binding to BSA in absence and in presence of site specific probes.

Effect of arsenic on paracetamol bound to BSA in presence of site I and site II specific probes Warfarin Sodium and Diazepam respectively

$3.0 \mathrm{ml}$ of previously prepared $2 \times 10^{-5} \mathrm{M}$ BSA solution was taken in each of seven previously cleaned and dried test tubes. $12 \mu \mathrm{L}$ of $1 \times 10^{-2} \mathrm{M}$ warfarin sodium solution was taken in each of six cleaned and dried test tubes. The final ratio between protein and warfarin was $1: 2\left(2 \times 10^{-5} \mathrm{M}: 4 \times 10^{-5} \mathrm{M}\right)$ in each of six test tubes. Then the site-I was sufficiently blocked by site-I specific probe. The seventh test tube containing only BSA solution was marked as blank. Paracetamol was added in five out of six test tubes so that protein, warfarin and paracetamol ratio

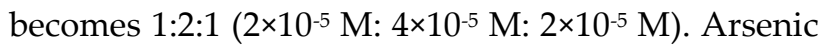
was added with an increasing concentration into four out of five test tubes containing 1:2:1 mixture of protein-warfarin-paracetamol to make the final ratio of protein, warfarin, paracetamol and arsenic 1:2:1:0, 1:2:1:1. 1:2:1:2, 1:2:1:4, 1:2:1:6. Arsenic was not added to one test tube. The solution mixture was then properly mixed and allowed to stand for 15 minutes for the confirmation of maximum binding to BSA. After 15 minutes the solutions were pipetted out and poured into seven different semi-permeable membrane tubes. Both the end of the membrane was clipped and was ensured that there was no leakage. The tubes containing drug mixture were immerged in seven $50 \mathrm{ml}$ conical flasks containing $30 \mathrm{ml}$ of phosphate buffer solution at $\mathrm{pH}$ 7.4. The conical flasks were then placed in a mechanical shaker and were shacked at $27^{\circ} \mathrm{C}$ temperature with $20 \mathrm{rpm}$ continuously for six hours uninterruptedly to complete the dialysis. After shaking is complete samples were collected from each flask. Free concentrations of paracetamol were measured by using a UV-VIS spectrophotometer at a wavelength of $246 \mathrm{~nm}$. The same procedure was followed when site II specific probe Diazepam was used.

\section{RESULT AND DISCUSSION}

Effect of arsenic on paracetamol binding to BSA in absence and in presence of site I and site II specific probes are shown in Figure 1. From the data analyzed different model of interaction between arsenic- paracetamol is proposed and presented at Figure 2 either in presence of site specific probes or in absence of site specific probes. The effect of arsenic on paracetamol in absence and in presence of site-I specific probe warfarin and site-II specific probe diazepam are shown in Figure 1. Free concentrations of paracetamol bound to BSA upon the addition of arsenic in absence of any of the two site specific probes was increased from $3.95 \pm 1.164 \%$ to $25.36 \pm 1.164 \%$ when arsenic to BSA ratio was increased from 1:1 to 1:8. In presence of site-I specific probe warfarin sodium the \% release of drug was found to be steady at around $14 \%$. But in presence of diazepam; site-II specific probe an increment of free drug concentration was observed (free paracetamol concentration increased from $14.38 \pm 1.164 \%$ to $54.72 \pm 1.552 \%$ when arsenic to BSA ratio increased from $1: 1$ to $1: 8$ ).

Thus we can speculate that the free concentration of paracetamol was increased to a greater extent in presence of arsenic and probably arsenic bound to site-II of BSA. In presence of site-I specific probe the effect of arsenic was not significant. So, arsenic may displace paracetamol by binding with high affinity binding site, site-II in the BSA and probably arsenic has little effect to site-I. According to Uddin et al. (2004), site I (warfarin site) is low affinity site while site-II (diazepam site) is high affinity site of arsenic to BSA binding. The findings from this current study complied with Uddin et al. in respect to arsenic-paracetamol binding pattern. 


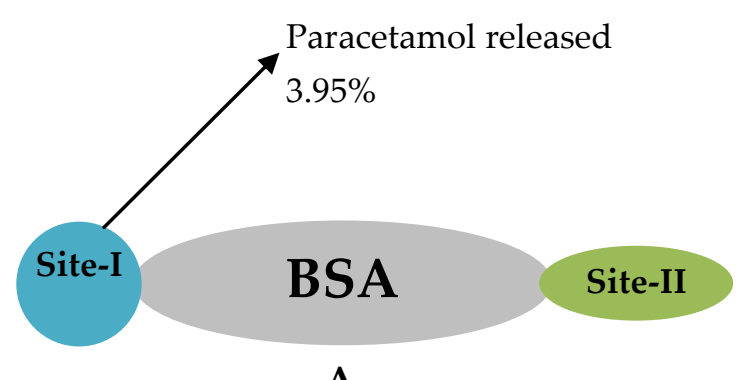

A

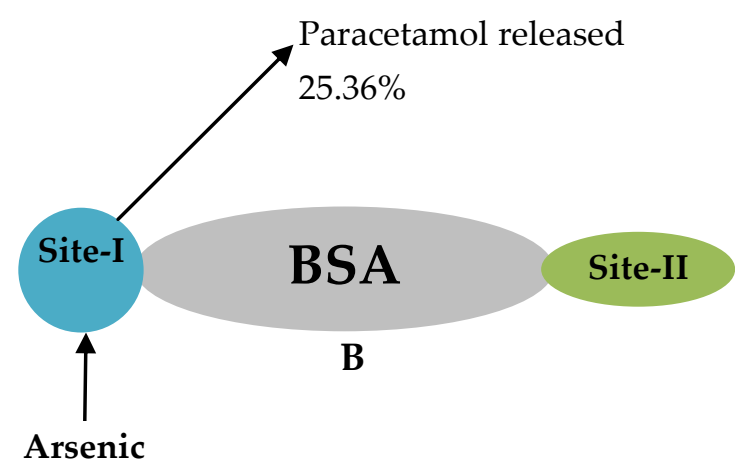

Arsenic

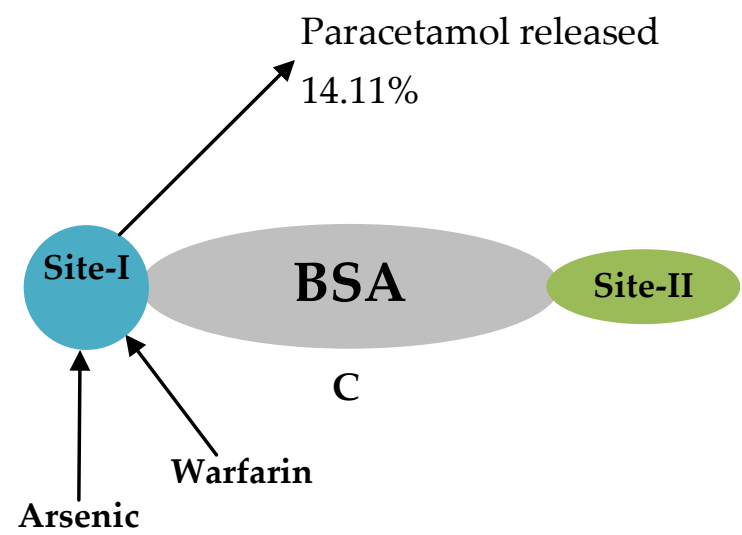

Paracetamol released

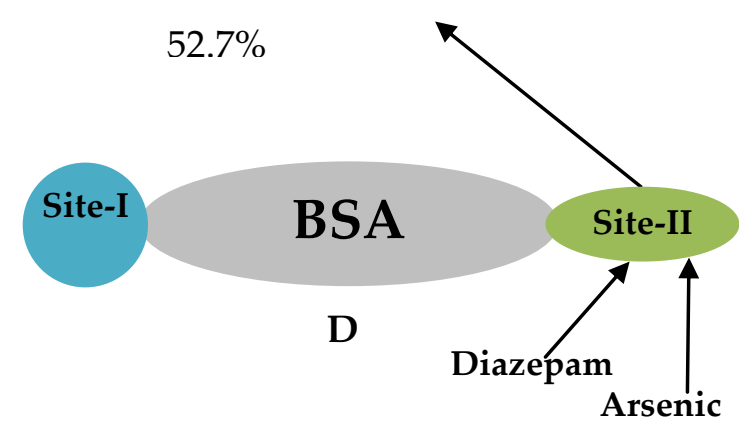

Figure 2: Proposed models of the paracetamol-BSAarsenic interaction in absence and in presence of site-I and site-II specific probe warfarin and diazepam respectively. (A) Normal binding of paracetamol to BSA, (B) Effect of arsenic on paracetamol binding to BSA, (C) Effect of arsenic on paracetamol binding to BSA in presence of warfarin, (D) Effect of arsenic on paracetamol binding in presence of diazepam.
The ability of one drug to inhibit the other is a function of their relative concentration, binding affinities and specificity of binding (Koch-Weser and Sellers, 1976). Since only a small fraction of drug would ordinarily be available in the free form, the displacement of even a small percentage of the amount of drug that is bound to proteins could produce considerable increase in activity (Uddin et al., 2005). In case of drug-drug interaction with arsenic the possibility of the occurrence of site to site displacement should also be considered as there will be a difference between the free concentration of a displaced drug with or without site to site displacement. Moreover, protein binding of a drug is not a phenomenon particular to plasma.

As per our findings in this study, it has been observed that arsenic increased the free drug concentration of paracetamol. It may lead to excessive pharmacological action of the said drug which may lead to toxicity and even paracetamol poisoning. In a previous study we found that the presence of arsenic warfarin is slowly displaced from its high affinity binding site with increasing paracetamol concentration (Alam et al., 2008). Paracetamol is associated with an increased hypoprothrombinemic effect of warfarin. This interaction was proposed due to inhibition of its metabolism and interference with formation of clotting factors. Gingival bleeding and hematuria were observed when paracetamol was given with warfarin (Hylek et al., 1998). Several case reports including case controlled studies have reported that paracetamol potentiates the anti-coagulant effect of warfarin (Andrews, 2002), others have not found a clinically relevant interaction (Fattinger et al., 2002). NSAIDs such as mefenamic acid (Holemes, 1966), etodolac (Ermer et al., 1994), ibuprofen (Penner and Abdrecht, 1975; Schulman and Henriksson, 1989) and tenidap (Apseloff et al., 1995) may also displace coumarin anti-coagulants from protein binding sites.

\section{CONCLUSION}

Considering all these aspects, facts and findings it can be concluded that the patients who are affected by arsenic should be careful of using NSAIDs. And the physicians should ensure therapeutic drug monitoring in case of prescribing NSAIDs to arsenic affected population. Proper care should be taken 
during prescribing paracetamol as it is evident from our study that arsenic potentially changes the pharmacokinetics of the drug during concurrent administration of arsenic and the drug.

\section{CONFLICT OF INTEREST}

Riaz Uddin is a member of the Editorial Board of International Current Pharmaceutical Journal. But this has got no persuasive role on the acceptance or publication of the manuscript. The other authors declare no conflict of interest.

\section{REFERENCES}

Alam, M.A., Uddin, R., Haque, S. (2008). Protein binding interaction of warfarin and acetaminophen in presence of arsenic and of the biological system. Bangladesh J Pharmacol. 3 (2): 49-54. [DOI]

Andrews, F.J. (2002). Retroperitoneal haematoma after paracetamol increased anticoagulation. Emerg Med J. 19: 84-85. [DOI] PMid:11777891 PMCid:1725766

Apseloff, G., Wilner, K.D., Gerber, N. (1995). Effect of tanidap sodium on the pharmacodynamics and plasma protein binding of warfarin in healthy volunteers. Br J Clin Pharmacol. 39 (Suppl 1): 29S-33S. [DOI] PMid:7547090 PMCid:1364933

Bower, W.A., Johns, M., Margolis, H.S., Williams, I.T., Bell, B.P. (2007). Population based surveillance for acute liver failure. Am J Gastroenterol. 102(11): 2459-63. [DOI] PMid:17608778

Dong, H., Haining, R.L., Thummel, K.E., Rettie, A.E., Nelson, S.D. (2000). Involvement of human cytochrome P450 2D6 in the bioactivation of acetaminophen. Drug Metab Dispos. 28(12): 1397-400. PMid:11095574

Ermer, J.C., Hicks, D.R., Wheeler, S.C., Kraml, M., Jusko, W.J. (1994). Concomitant etodolac affects neither the unbound clearance nor the pharmacologic effect of warfarin. Clin Pharmacol Ther. 55: 863-67. [DOI] PMid:8143396

Fattinger, K., Frisullo, R., Masche, U., Braunschweig, S., Meier, P.J., Roos, M. (2002). No clinically relevant drug interaction between paracetamol and phenprocoumon based on a pharmacoepidemiological cohort study in medical inpatients. Eur J Clin Pharmacol. 57(12): 863-7. [DOI] PMid:11936705

Holmes, E.L. (1966). Experimental observations on flufenamic, mefenamic, and meclofenamic acids. IV. Toleration by normal human subjects. Ann Phys Med. 9 (Suppl): 36-49.

Hylek, E.M., Heiman, H., Skates, S.J., Sheehan, M.A., Singer, D.E. (1998). Acetaminophen and other risk factors for excessive warfarin anticoagulation. JAMA. 279(9): 657-62. [DOI]

Koch-Weser, J., Sellers, E.M. (1976). Binding of Drugs to Serum Albumin (first of two parts). N Engl J Med. 294: 311-16. [DOI] PMid:1107839

Lee, W.M. (2004). Acetaminophen and the U.S. Acute Liver Failure Study Group: lowering the risks of hepatic failure. Hepatology. 40(1): 6-9. [DOI] PMid:15239078
Penner, J.A., Abbrecht, P.H. (1975). Lack of interaction between ibuprofen and warfarin. Curr Ther Res Clin Exp. 18(6): 862-71. PMid:813951

Rahman, M.H., Yamasaki, K., Shin, Y.H., Lin, C.C., Otagiri, M. (1993). Characterization of high affinity binding sites of nonsteroidal anti-inflammatory drugs with respect to site-specific probes on human serum albumin. Biol Pharm Bull. 16(11): 1169-74. [DOI]

Schulman, S., Henrikson, K. (1989). Interaction of ibuprofen and warfarin on primary haemostasis. Br J Rhematol. 28: 46-49. [DOI]

Sheen, C.L., Dillon, J.F., Bateman, D.N., Simpson, K.J., Macdonald, T.M. (2002). Paracetamol toxicity: epidemiology, prevention and costs to the health-care system. QJM. 95(9): 609-19. [DOI] PMid:12205339

Singlas, E. (1987). Determination of protein binding and its characteristics: Protein binding of drugs. (2nd ed.) HoffmanLa Roche. Switzerland.

Sudlow, G., Birkett, D.J., Wade, D.N. (1975). The Characterization of Two Specific Drug Binding Sites on Human Serum Albumin. Molecular Pharmacology. 11(6): 824-32. PMid:1207674

Sudlow, G., Birkett, D.J., Wade, D.N. (1976). Further Characterization of Two Specific Drug Binding Sites on Human Serum Albumin. Molecular Pharmacology. 12: 1052-61. PMid:1004490

Uddin, R., Huda, N.H. (2011). Arsenic Poisoning in Bangladesh. Oman Medical Journal. 26(3): 207. [DOI] PMid:22043419 PMCid:3191694

Uddin, R., Saffoon, N., Alam, M.A. (2011). Arsenic, the poison and poisoned groundwater of Bangladesh: A review. International Current Pharmaceutical Journal. 1(1): 12-17. [DOI]

Uddin, R., Saffoon, N., Alam, M.A. (2012). Protein Binding Interaction. LAP Lambert Academic Publishing AG \& Co. KG. Germany. ISBN-13: 9783659001802.

Uddin, S.J., Rouf, R., Sen, P.K., Alam, M.A., Sarder, M.M., Alam, S.M.M. et al. (2005). In-vitro studies of the effect of arsenic on the binding of metronidazole at the binding sites of bovine serum albumin. Khulna Univ Stud. 6: 73-6.

Uddin, S.J., Shilpi, J.A., Murshid, G.M.M., Rahman, A.A., Sarder, M.M., Alam, M.A. (2004). Determination of the binding sites of arsenic on bovine serum albumin using warfarin (site-I specific probe) and diazepam (site-II specific probe). J Biolog Sci. 4: 609-12. [DOI]

Wasserman, G.A., Liu, X., Parvez, F., Ahsan, H., Factor-Litvak, P., van Geen, A. et al. (2004). Water arsenic exposure and children's intellectual function in Araihazar, Bangladesh. Environ Health Perspect. 112(13): 1329-33. [DOI] PMid:15345348 PMCid:1247525

WHO (2007). Drug information. 15th model list of essential medicines. Volume 21, No. 2. 